\title{
Review with checklist of Fabaceae in the herbarium of Iraq natural history museum
}

\author{
Khansaa Rasheed Al-Joboury* \\ Iraq Natural History Research Center and Museum, University of Baghdad, Baghdad, Iraq.
}

GSC Biological and Pharmaceutical Sciences, 2021, 14(03), 137-142

Publication history: Received on 08 February 2021; revised on 10 March 2021; accepted on 12 March 2021

Article DOI: https://doi.org/10.30574/gscbps.2021.14.3.0074

\begin{abstract}
This study aimed to make an inventory of leguminous plants for the purpose of identifying the plants that were collected over long periods and stored in the herbarium of Iraq Natural History Museum. It was found that the herbarium contains a large and varied number of plants from different parts of Iraq and in different and varied environments. It was collected and arranged according to a specific system in the herbarium to remain an important source for all graduate students and researchers to take advantage of these plants. Also, the flowering and fruiting periods of these plants in Iraq were recorded for different regions. Most of these plants begin to flower in the spring and thrive in fields and farms.
\end{abstract}

Keywords: Fabaceae; Herbarium; Iraq; Natural; History; Museum

\section{Introduction}

Leguminosae, Fabaceae or Papilionaceae, which was called as legume, pea, or bean Family, belong to the Order of Fabales [1]. The Fabaceae family have 727 genera also 19,325 species, which contents herbs, shrubs, trees, and climbers [2]. The distribution of fabaceae family was variety especially in cold mountainous regions for Europe, Asia and North America, It is also abundant in Central Asia and is characterized by great economic importance. It is one of the three most important plant families for flowering plants [3]. The leaves of Fabaceae family are stipulate, alternate, pinnately or palmately. The petioles base are enlarged to a pulvinus [4]. Also the flower is perigynous, zygomorphic, racemes, spikes, or heads, And the perianth have a calyx and corolla for five segments [5]. The Fabaceae family has petals which are overlapping in bud and the posterior petal outermost in position. The androecium have 10 stamens in two [6]. The pistils are simple, divided into a single style and stigma, also a superior ovary have one locule divided to 2-many marginal ovules. The fruits are always legume [7]. The Fabaceae family are particularly diverse in all tropical forests and temperate shrublands [8].

\section{Material and methods}

All specimens of Fabaceae family in various habitats of Iraq and saved in the herbarium of Iraq Natural History Museum was written down and studied its geographical distribution. Used many taxonomic keys identification and diagnosed genera such as: $[9.10,11,12]$.

\section{Results and discussion}

In this study checklist of fabaceae in the herbarium of Iraq Natural History Museum showed many genera as fallow:

\footnotetext{
${ }^{*}$ Corresponding author: Khansaa Rasheed Al-Joboury

Iraq Natural History Research Center and Museum, University of Baghdad, Baghdad, Iraq. 
Acacia Mill., 1754

In the herbarium of Iraq Natural History Museum it was found two species which were they Acacia nilotica (L.) Delile and Acacia gerrardii Benth.

HAB. Acacia nilotica (L.) Delile, Alluvial desert, near a date garden, alt. c. 2 m. , fl. Sept.- Dec., fr. July- Dec.

HAB. Acacia gerrardii Benth., Sandy gravel desert in a broad open wadi, alt. c. 250 m., fl. Jun.-Jul., fr. Oct.- Nov.

Amorpha L., 1753

In the herbarium of Iraq Natural History Museum it was found one species which was Amorpha fruticosa L.

HAB. Amorpha fruticosa L., cultivated in gardens in the desert region of Iraq, alt. 35 m., fl. Apri.- May.

Alhagi Adans., 1763

In the herbarium of Iraq Natural History Museum it was found two species which were they Alhagi maurorum Medik. and Alhagi graecorum Boiss.

Alhagi maurorum Medik. Alluvial soil in valley on limestone, alt. 650 m., fl. and fr. Aug.

Alhagi graecorum Boiss., lower mountain valley sides, orchards and garden, ditches and canal banks, up to alt. 1500 m. fl. Jun.- Aug., fr. Aug.-Dec.

Albizia Durazz, 1772

In the herbarium of Iraq Natural History Museum it was found one species which was Albizia lebbeck (L.) Benth.

HAB. Cultivated in parks and gardens, along canals and quays, up to c.50m

Fl. May- June

Fr. Dec.- Feb.

Astragalus L., 1753

In the herbarium of Iraq Natural History Museum it was found many species which were they Astragalus bruguieri Boiss., Astragalus campylorrhynchus Fisch. \& C.A.Mey., Astragalus corrugatus Bertol., , Astragalus alexandrii Kharadze, Astragalus amblytropis Barneby, Astragalus ancistrocarpus Boiss. \& Hausskn., Astragalus spinosus Astragalus schimperi Boiss., Astragalus tribuloides Delile, Astragalus porphyrodon C.C.Towns, Astragalus oocephalus Boiss., Astragalus gillettii C.C.Towns, Astragalus alyssoides Lam., Astragalus echinops Boiss., Astragalus brachycarpus M.Bieb., Astragalus pulcher Korovin, Astragalus mollissimus Torr., Astragalus dendroproselius Rech.f., Astragalus dactylocarpus Boiss., Astragalus gattatus, Astragalus oxyglottis M.Bieb.,

Bauhinia L., 1753

In the herbarium of Iraq Natural History Museum it was found one species which was Bauhinia rasimosa Lam.

HAB. Bauhinia rasimosa Lam. Cultivated in desert region in Iraq.

Caesalpinia L. 1753

In the herbarium of Iraq Natural History Museum it was found one species which was Caesalpinia gilliesii (Hook.) D.Dietr.

HAB. Caesalpinia gilliesii (Hook.) D.Dietr. cultivated in gardens up to 50 m. alt., fl. Jun.-Aug., fr. Sep.-Nov. 
Cassia L. 1753

In the herbarium of Iraq Natural History Museum it was found one species which was Cassia fistula L.

HAB. Cassia fistula L. cultivated in the southern sector of the region of Iraq.

Ceratonia L. , 1753

In the herbarium of Iraq Natural History Museum it was found one species which was Ceratonia siliqua L.

HAB. Ceratonia siliqua L. cultivated in in the desert of Iraq, alt. c. 35 m., fl. And fr. Apr.

Cicer L., 1753

In the herbarium of Iraq Natural History Museum it was found one species which was Cicer arietinum L.

HAB. Cicer arietinum L. mountains slopes in grassy places, cultivated hillsides, alt. up to 1900 m., fl. And fr. May- July.

Colutea L. 1753

In the herbarium of Iraq Natural History Museum it was found one species which was Colutea cilicica Boiss. \& Balansa

HAB. Colutea cilicica Boiss. \& Balansa rocky mountain slope, in a ravin, open places in oak forest, alt. 950-1900 m., fl. And fr. May- June.

Coronilla L. 1753

In the herbarium of Iraq Natural History Museum it was found one species which was Coronilla scorpioides (L.) Koch

HAB. Coronilla scorpioides (L.) Koch upland slopes on clay soils, alt. 200-1000 m., fl. And fr. Apr.- June.

\section{Dalbergia L.f.}

In the herbarium of Iraq Natural History Museum it was found one species which was Dalbergia sissoo DC.

HAB. Dalbergia sissoo DC. Cultivated in the steppe and desert region of Iraq., uo to alt. 250-300 m., fi. And fr. Apr.-Oct.

Gleditsia L. 1753

In the herbarium of Iraq Natural History Museum it was found one species which was Gleditsia triacanthos L.

Glycyrrhiza L.

In the herbarium of Iraq Natural History Museum it was found one species which was Glycyrrhiza glabra L.

Hippocrepis L., 1753

In the herbarium of Iraq Natural History Museum it was found one species which was Hippocrepis unisiliquosa L

Hymenocarpos Savi

In the herbarium of Iraq Natural History Museum it was found one species which was Hymenocarpos circinnatus (L.) Savi

Leucaena Benth., 1842

In the herbarium of Iraq Natural History Museum it was found one species which was Leucaena leucocephala (Lam.) de Wit 
HAB. Cultivated gardens up to alt.c.50 m.

fl. May-October

fr. July- November

Lathyrus L.

In the herbarium of Iraq Natural History Museum it was found many species which were they Lathyrus aphaca L., Lathyrus annuus L., Lathyrus cassius Boiss., Lathyrus inconspicuus L., Lathyrus cicera L., Lathyrus hirsutus L., Lathyrus sativus L.

Lotus L., 1753

In the herbarium of Iraq Natural History Museum it was found many species which were they Lotus gebelia Vent., Lotus corniculatus L., Lotus lanuginosus Vent

HAB. Lotus gebelia Vent. Common in the forest zone of Iraq, and in oak forest, alt. 600-2300 m., fl. And fl. May- June.

HAB. Lotus corniculatus L. common in the forest zone of Iraq, on mountains slopes, up to alt. 2400 m., fl. And fr. JuneAug. in the mountains Mar.-May. On the lower plain.

HAB. Lotus lanuginosus Vent, desert plains, alt. 50-600 m., fl. And Fr. Mar.- June.

Lens Mill.

In the herbarium of Iraq Natural History Museum it was found many species which were they Lens orientalis (Boiss.) Schmalh., Lens culinaris Medik [13].

Medicago L.

In the herbarium of Iraq Natural History Museum it was found many species which were they Medicago phrygia (Boiss. \& Balansa) E.Small, Medicago monspeliaca (L.) Trautv., Medicago monantha (C.A.Mey.) Trautv., Medicago sativa L., Medicago orbicularis (L.) Bartal., Medicago laciniata (L.) Mill., Medicago ciliaris (L.) Krock., Medicago lupulina L., Medicago polymorpha L., Medicago coronata (L.) Bartal [14].

\section{Melilotus Mill.}

Melilotus indicus (L.) All. In dry steppic plains, sandy gravel, up to alt. c. 250 m. fl. And fr. Mar.- Apr [15,16].

Onobrychis Mill.

In the herbarium of Iraq Natural History Museum it was found many species which were they Onobrychis ptolemaica (Delile) DC., Onobrychis acaulis Bornm., Onobrychis caput-galli (L.) Lam., Onobrychis schahuensis Bornm.

Ononis L., 1753

In the herbarium of Iraq Natural History Museum it was found many species which were they Ononis viscosa L., Ononis spinosa L.

HAB. Ononis viscosa L., in one district of the N.E. sector of the lower forest zone of Iraq.

HAB. Ononis spinosa L., mountain slopes, in oak forest, destroyed forest and above tree line, alt. 650-2500m., fl. MayAug., fr. Jul.-Sept.

Parkinsonia L.

In the herbarium of Iraq Natural History Museum it was found one species which was Parkinsonia aculeata L. 
Pisum L.

In the herbarium of Iraq Natural History Museum it was found one species which was Pisum sativum L.

HAB. Pisum sativum L. in the forest zone of Iraq, grassy mountains slopes, cultivated in grain field, alt. 700-1600 m., fl. And fr. Apr.-May.

Prosopis L., 1767

In the herbarium of Iraq Natural History Museum it was found many species which were they Prosopis juliflora (Sw.) DC., Prosopis farcta (Banks \& Sol.) J.F.Macbr.

HAB. Prosopis juliflora (Sw.) DC. Mountain valleys, in open forest, on arable land, up to alt. 1500 m., fl.

HAB. Prosopis farcta (Banks \& Sol.) J.F.Macbr. cultivated in gardens in the desert region of Iraq, up to alt. 50 m., fl. AprilMay, fr. July-February.

Trifolium L., 1753

In the herbarium of Iraq Natural History Museum it was found many species which were they Trifolium campestre Schreb., Trifolium echinatum M.Bieb., Trifolium fragiferum L., Trifolium hirtum All., , Trifolium lappaceum L., Trifolium leucanthum M.Bieb., Trifolium medium L., Trifolium nigrescens Viv. Trifolium purpureum Loisel., Trifolium pilulare Boiss., Trifolium repens $L_{\text {., }}$ Trifolium resupinatum L., Trifolium scabrum L., Trifolium stellatum L., Trifolium spumosum L., Trifolium tomentosum L., Trifolium grandiflorum Schreb [17,18].

\section{Trigonella L.}

In the herbarium of Iraq Natural History Museum it was found many species which were they Trigonella astroides Fisch. \& C.A.Mey., Trigonella caelesyriaca Boiss., Trigonella hamosa Del. ex Smith, Trigonella foenum-graecum L., Trigonella filipes Boiss., Trigonella stellata Forssk., Trigonella spicata Sm., Trigonella uncinata Banks \& Sol.

Vicia L., 1824

In the herbarium of Iraq Natural History Museum it was found many species which were they Vicia tenuifolia Roth, Vicia ervilia (L.) Willd., Vicia tenera Benth., Vicia narbomerpis L., Vicia monantha Retz., Vicia michauxii Spreng., Vicia hybrida L., Vicia sativa L., Vicia palaestina Boiss., Vicia assyriaca Boiss.

Vigna Savi, 1824

In the herbarium of Iraq Natural History Museum it was found many species which were they Vigna radiata (L.) R.Wilczek, Vigna unguiculata (L.) Walp.

HAB. Vigna radiata (L.) R.Wilczek, cultivated as a summer pulse crop in Iraq. Up to alt. $50 \mathrm{~m}$.

HAB. Vigna unguiculata (L.) Walp, cultivated on the lower alluvial plain in the desert region of Iraq., up to alt. c. $50 \mathrm{~m}$.

fl. And fr. Jun.- Oct.

Legumes were very widely distributed, and the third-largest land plant family at terms for number of species, behind the families Orchidaceae and Asteraceae.

\section{Conclusion}

The study showed the genus and species of the leguminous family which found in the herbarium of Iraq Natural History Museum and their spread in various as they are the most important widespread plant families and bear many difficult environmental conditions. Therefore, it will be a reference for many researchers and those interested in this aspect. 


\section{Compliance with ethical standards}

\section{Acknowledgments}

The author is very grateful to university of Baghdad for helping me complete this research.

\section{Disclosure of conflict of interest}

There's no conflict of interest in this research.

\section{References}

[1] Sprent JI. Nodulation in legumes. Kew: Royal Botanic Gardens. 2001; 146.

[2] Estrella M, Xander MB, Mackinder BA, Devesa JA, James M. Gilbertiodendron tonkolili (LeguminosaeCaesalpinioideae) a new species from Sierra Leone. Nordic Journal of Botany. 2012; 30: 136-143.

[3] Diniz MR, Silva GS, Conceição GM. New occurrences for Maranhão of species of Papilionoideae, deposited in the Herbarium HABIT, of the Center of Higher Studies of Caxias, Maranhão. Biota Amazônia. 2017; 7(4): 57-59.

[4] Sheikh N, Desai T, Patel R. Pharmacognostic Evaluation of Melilotus officinalis Linn. Pharmacognjournal. 2016; 8: $239-242$.

[5] Gomes GS, Silva GS, Conceição GM. Floristic taxonomy of clado mimosoide (Fabaceae, Caesalpinioideae) in the municipality of são joão do sóter. Maranhão, Brazil. Agrarian Academy. 2017; 4(8): 13.

[6] Haerinasab M, Rahiminejad M. A taxonomic revision of the genus Trifolium L. sect. Fragifera Koch (Fabaceae) in Iran. Iranian journal of botany. 2012; 18: 22-30.

[7] Amorim IDM, Sousa IOF, Oliveira FFM, Camacho RGV, Melo JIM. Fabaceae in the National Forest (FLONA) of Assú, semiarid region of northern Brazil. Rodriguésia. 2016; 67(1): 105-123.

[8] Marwat S, Khan A, Ahmad M, Zafar M, Ahmad F, Nazir A. Taxonomic studies of nodulated leguminous weeds from the flora of North Western part (Dera Ismail Khan) of Pakistan. African Journal of Biotechnology. 2009; 8: 21632168.

[9] Townsend C, Guest E. Flora of Iraqi. Vol.3. Ministry of Agriculture and Agarain reform. Baghdad, Iraqi. 1974.

[10] Khansaa RA, Lubab GA, Sukeyna AA. Morphological, anatomical and numerical taxonomy studies for some species of the fabaceae family. Journal of Biodiversity and Environmental Sciences. 2017; 11(5): 117-123.

[11] Lewis GP, Forest F. Tribe Cercideae. In: Lewis G, Schire B, Mackinder B, Lock M. Legumes of the world. Royal Botanical Gardens, Kew. 2005; 57-67.

[12] Schnurr J, Jung G, Samac D. A comparative study of alfalfa and Medicago truncatula stem traits: morphology, chemical composition and ruminal digestibility. Crop Science. 2007; 47: 1672-1680.

[13] Rasool G, Qaiser M. A numerical taxonomy of the genus Sedum l. from Pakistan and Kashmir. Pakistan Journal of Botany. 2011; 43: 753-758.

[14] Wang L, Grusak M. Structure and development of Medicago truncatula pod wall and seed coat. Annals of Botany. 2005; 95: 737-747.

[15] Sheikh N, Desai T, Patel R. Pharmacognostic Evaluation of Melilotus officinalis Linn. Pharmacognjournal. 2016; 8: $239-242$.

[16] Özbek F, Ufuk M, Ekici M. Morphological, anatomical, pollen and seed morphological properties of Melilotus bicolor Boiss. \& Balansa (Fabaceae) endemic to Turkey. Australian Journal of Crop Science. 2014; 8: 543-549.

[17] Zoric L, Merkulov L, Lukovic J, Boza P. Comparative analysis of qualitative anatomical characters of Trifolium L. (Fabaceae) and their taxonomic implications: preliminary results. Plant Systematics and Evolution. 2012; 298: 205-219.

[18] Haerinasab M, Rahiminejad M. A taxonomic revision of the genus Trifolium L. sect. Fragifera Koch (Fabaceae) in Iran. Iranian journal of botany. 2012; 18: 22-30. 